\title{
Research on Interactivity of Design of Environmental Ceramic Art
}

\author{
Yiling Tang \\ College of Art and Design, Hunan International Economics University, Changsha, 410205, China
}

Keywords: Environmental ceramic art, Design, Interactivity

\begin{abstract}
On the basis of a specific analysis on the concept of design of environmental ceramic art, the author makes an in-depth analysis on component elements of interactivity of environmental ceramic design as well as interactive relationship among various elements. Moreover, the author also discusses relevant design elements influencing interactivity, with expectations to improve the whole artistic level of urban public life, gradually promote public life in modern society toward artistic development, and promote further promotion and application of environmental ceramic art in modern society.
\end{abstract}

\section{Introduction}

Design of environmental ceramic art, a new concept of public art design, obtained new development with the improvement to the people's living standards and higher artistic requirements for living environment. Besides, it has significant influence on public art design and development of ceramic art in China.

\section{Formation of the concept of environmental ceramic design}

The concept of environmental ceramic design began in the 1980s - 1990s. At that time, China was in the initial stage for reform and opening-up. National economy got rapid development. Under the influence of the reform and opening-up, China's economic and cultural exchange with various countries was gradually enhanced. At the same time, improvement was also made to the people's field of vision and spiritual state. Such improvement had positive influence on the development of design of environmental ceramic art. To some extent, it promoted continuous improvement to application scope and quality of design of environmental ceramic art. At first, appearance of the concept of environmental ceramic design is closely correlated with the rise of modern environmental ceramic art in the world. Modern environmental ceramic art started in the later stage of World War II. It was formally proposed by Peter Voulkos, an American ceramic artist. On the level of subjective research, Voulkos gave up practical value of ceramic art on material level in social application, laid the emphasis of ceramic design on spiritual and artistic pursuit of ceramic art, and devoted himself to improving aesthetic value of ceramic art. Voulkos has profound influence on further development of environmental ceramic design in the future. After the 1980s, China's modern ceramic art gradually became mature under the influence from the concept of ceramic design in western modern society. Influenced by Voulkos's thought, aesthetic value of ceramics in environmental construction was taken as the key point of artistic design, getting rid of the constraint of Chinese ceramic art concept for the development of modern ceramic art. To some extent, the transition of this ideology led modern environmental ceramic art to independent from traditional ceramic art and to really break through the limitation of practicability. In practical creation, deeper researches were made on external form, material and language of ceramic art. In the new period, more excellent environmental ceramic art works were created. While creating environmental ceramic art, modern Chinese ceramic artists permeated their creative ideas into public environmental construction through the material form of ceramic art, forming the space of public environment with strong artistic atmosphere, and tremendously expanding the field of practical creation of modern environmental ceramic art. On this basis, a new artistic concept was gradually derived, i.e. environmental ceramic design. Appearance of the concept of environmental ceramic design trended to be obvious under the influence of two concepts (i.e. appearance of modern environmental ceramic art and public environmental art). 
Therefore, environmental ceramic design is closely correlated with public environmental art in the field of artistic creation. Environmental ceramic design can even be affirmed as an important branch of public environmental design according to specific research scopes of both items. Therefore, an attempt can be made in the research to define environmental ceramic design: environmental ceramic design is a process of public environment art design with the material form of ceramics as the major medium with the purpose of meeting the public's spiritual and material needs. In other words, artistic designers conceive ceramic images with the way of thinking of artistic design according to certain environment constitution needs, and finally design or create ceramic art compatible with the environment for mutual development with ceramics as the principal carrying material of artistic creation. It can be put in this way: in public environmental construction, environmental ceramic design is a process of artistic creation. At the same time, it is also expressed as the final result of artistic design.

\section{Component elements of interactivity of environmental ceramic design}

Environmental ceramic design works substantially give expression to a kind of interaction among artists, design works and the public. To be specific, this type of interaction is realized by interactive relationship among works, participators and the environment. Thus, it can be seen that interactivity of environmental ceramic design includes the following three component elements: work. human and environment. Then, a specific analysis will be made on the three elements:

\section{Three interactive elements of environmental ceramic art}

The first element is ceramic work. Ceramic art is a kind of artistic form integrated with water, fire and earth. Water makes dry earth to be plastic. Moreover, such plasticity promotes initial development of ceramic art to some extent. Ceramic designers elaborately select earth with strong plasticity after mixing with water. Then, they create containers in various shapes according to their imagination, giving further expression to the probability of ceramic modeling. With gradual improvement to the people's art appreciation level and aesthetic ability, designers begin to draw various patterns in ceramic modeling according to specific needs, showing their ideal of beauty of ceramic work $^{[1]}$. However, the use of fire really converts the modeling of earth into ceramics, making ceramics become a kind of container with practicability and artistic quality as well as unique artistic charm. In the process of conversion, it cannot be guaranteed that the whole conversion process is under the control of human. To the extent, it contributes a lot to mystery and interestingness of ceramic art. At the same time, fire is reasonably used in ceramic creation. Therefore, ceramic works are generally featured by stiffness and pollution free. In particular, some artistic works fired with the process of glazing can form a unique substance with the attribute of glass on the surface of ceramics. Such substance can effectively isolate dirt and prevent ceramics from weathering. Thus, it is guaranteed that ceramic works can still maintain the original luster after spreading over for a long period of time. It can be said that the most outstanding visual effect of ceramic works after artistic creation is colorful glazing color. With further development of science and technology in modern society, more and more glazing colors can be created in ceramic creation. Richness of color and pattern of manifestation is greatly expanded. Each color can be expressed through three forms: glazed, matt and dark. Ceramic works are generated from plain earth, and finally become bright and elegant ceramic art after human's artistic creation. Influenced by surface glaze, ceramic work will never fade. This feature really makes ceramic art to have further development in the history. It always represents an elegant form of art. To some extent, this feature provides relevant convenience to the development of environmental ceramic design.

The first element is human. In environmental ceramic design, human has two important meanings. In the one hand, it refers to specific designers of ceramic design. Influenced by self capacity, habit of thought and art, aesthetic tendency and other factors, different designers will certainly design different works and manifest as different forms, connotations and features while facing the same public environment. Design level and design thought of a designer have decisive influence on the quality of work and the degree of acceptability of the public. On the other hand, it refers to receivers 
of environmental ceramic design, i.e. humans living in the environmental space of public environmental ceramic design. Receiving groups of environmental ceramic art also have corresponding influence on artistic creation.

The first element is the environment. Viewed from material level, environment can be specifically divided into natural environment and artificial environment. Viewed from psychological level, environment can be divided into the environment with physical nature and geographical nature and the environment with psychological nature and behavioral nature. From the research level of biology, environment can be divided into biological environment and non-biological environment. In modern society, the environment in environmental ceramic design refers to a kind of comprehensive environment integrated with man-made environment and natural environment. In in-depth researches, it is usually psychologically analyzed. Environment is formally interpreted and analyzed from two levels of physics and psychology. Under normal circumstances, physical environment is of corresponding stability. It will not change with the change of group consciousness in the living environment. It is relatively objective. However, psychological environment has certain subjectivity. It is formed by mental disposition of human. Therefore, it is instable in most cases. Psychological environment represents human's reaction to objective facts. However, it cannot be completely equalized with psychological reaction made under stimulus of objective environment. It is a kind of real psychological effect of subjective psychology in the environment gradually formed with time development and expansion in corresponding psychological space-time. It is the same as square frequently seen in a city. For a peasant who never steps into a city and a resident living in the city, they certainly differ a lot from each other in terms of psychological environment formed in respective city spares. Therefore, environmental ceramic design attaches more importance to psychology of this environment while paying attention to physical nature of the environment designed. That is to say, we should lay emphasis on humans in the environment.

\section{Interactive relationship among various elements in environmental ceramic design}

Interactivity is one of the most important natures in the development of public art. At the same time, it is also extensible development of public art in modern society. To some extent, construction of interactive relationship in artistic creation constitutes a kind of communication and exchange system with the nature of interaction that takes individual humans as the center and relevant artistic works as the carrier and that can result in an interaction between works and the environment, between human and work and between human and overall environment ${ }^{[2]}$. Only in interactive relationship and in wide contact with audiences, artistic value, social value and aesthetic value of artistic works can be really and smoothly realized. More importantly, the purpose of making environmental design to service the public can be achieved at last.

Interactive relationship of mutual influence and communication exists in realistic environment of environmental ceramic design and the public: specific pattern of manifestation of environmental ceramic design is influenced by its environment characteristics. After the completion of environmental ceramic works, it will certainly have corresponding influence on its environment. At the same time, environmental ceramic design influences visual, touch and other sensual perceptions of the public through its artistic quality and external entity images in the environment. Finally, it will act on the public's psychological cognition for this environment and induce the public to generate different behavioral reactions. However, relevant behaviors of the public generated under the influence of environmental ceramic design will certainly have influence on the surroundings. Therefore, it can be said that interactive relationship among the public, environmental ceramic design and the environment directly constitutes interactive relationship between human and environmental ceramic design, between environmental ceramic design and the environment and between human and the environment, making environmental ceramic design to have corresponding interaction.

Environmental ceramic design is modern ceramic artistic work with artificial influence in public environmental design in modern society. The public environment of environmental ceramic design has particularity. Therefore, it has certain public consciousness and space environmental development consciousness. As an important pattern of manifestation of public art construction and 
development in modern social construction, environmental ceramic design gradually seeks for good communication and exchange with the public in the status of reception with continuous changes of various functions in public art research. At the same time, ceramic materials necessary for environmental ceramic design have great advantages in terms of physical property and artistic expression. To some extent, these materials promote environmental ceramic design to be more beneficial for improvement to the overall artistic quality of the environment and for enhancement of interaction and exchange among the environment, design work and the public.

\section{Relevant factors influencing interactivity of environmental ceramic design}

\section{Influencing factors}

In the interactive process of three elements of environmental ceramic design, environmental ceramic design is always in the status of carrier of interaction. Environmental ceramic design maintains interactive relationship between designers and the public through its interaction with the public and the environment ${ }^{[3]}$. In this process, specific interactivity of environmental ceramic design refers to the level of interaction among the public, specific design work and the environment induced through artistic design under the influence from design. This is influenced by the selection of theme, design form and display \& use function in environmental ceramic design. At the same time, it is also correlated with the public's quality and relevant characteristics of surrounding environment. Therefore, factors influencing environmental ceramic design and deciding its interactivity include the theme of design, constitution form, territoriality, functionality, acceptance and participation.

\section{Relationship among influencing factors}

Corresponding interaction also exists among various factors influencing environmental ceramic design. Such interaction needs to take the nature of acceptance of design as a precondition. In other words, we should guarantee in the design that design works formed under other influencing factors can be accepted by the public. Only in this way, artistic design can be made to have interactivity. On the premise of the nature of acceptance guaranteed, interactive relationship among other influencing factors is shown in Fig. 1. It is systematic.

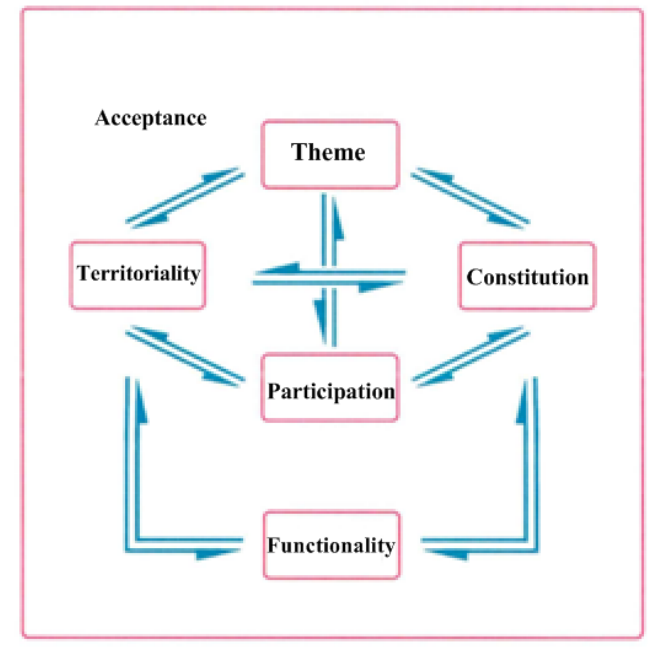

Fig. 1. Relationship of Major Factors Influencing Interactivity of Environmental Ceramic Design

\section{Conclusion}

In a word, environmental ceramic design is generally incorporated into the environment of design works in the research. It is analyzed and judged with the concordance between the environment and ceramic design, so as to guarantee objectivity and scientificity of the research. At the same time, we should also pay attention to certain personality characteristics of ceramic design in the research. At present, a relatively complete system of artistic expression has already been established. Therefore, interactivity, as an important part of research system, should receive great attention from researchers. 
Certain theoretical supports should be provided to practical operation of environmental ceramic design through the research.

\section{References}

[1] Zhang Li, Research on Interactivity of Environmental Ceramic Art, Central South University of Forestry and Technology, 2013;

[2] Zhan Wei, Discussion on the Relationship between Modern Environmental Ceramic Art and Multidisciplinary Category, Arts Criticism, 2013 (8): 108-109;

[3] Zhang Jing, Interpretation of Environmental Ceramic Art, Yi Shu Shi Shang, 2014 (10): 239-239 